\title{
Post-COVID-19 Sustainable Architecture Design Studio
}

\author{
Pattaranan Takkanon \\ Department of Building Innovation, Faculty of Architecture, Kasetsart University \\ 50 Ngamwongwan Road, Lat Yao, Chatuchak, Bangkok, Thailand \\ Email: pattaranan.t@ku.th
}

\begin{abstract}
COVID-19 outbreak has set the beginning of new normal to many parts of the world. The impact of COVID-19 was recognized in all sectors, including the higher education. Many new ways of teaching and learning are taking place. Despite lockdowns and social distancing that transformed on-site classrooms to online classrooms, architecture design studio programs should also adapt and respond to COVID-19 pandemic as well as contribute to the society by taking the real-world projects. The architectural program of Department of Building Innovation, Faculty of Architecture, Kasetsart University in Bangkok took the initiative in designing studio project programs to acknowledge the new normal. The programs were assigned to 2nd year Sustainable Architecture Design Studio during the 1st semester (July-November) of academic year 2020. Physical distancing, passive design, especially ventilation strategies, were the focus. Means to prove design performance include calculation and Computational Fluid Dynamics (CFD) methods. The paper shows results of post-COVID-19 eco canteen and 50-bed hospital design programs.
\end{abstract}

Keywords: post-COVID-19, design studio, sustainable architecture, passive design, ventilation.

\section{Introduction}

The Bachelor of Science in Architecture (BBIT) is a new program introduced by the Department of Building Innovation, the Faculty of Architecture, Kasetsart University in 2016. It targets at shaping students to become architects of the new era who not only can design buildings but also have abilities to prove environmental performance of the design scientifically. Design studio courses are crucial to prepare architecture students for their future profession especially in the field of sustainable architecture as they are platforms for integration and application of comprehensive knowledge. In response to COVID-19 pandemic, design studio programs were re-designed to tackle health issues regarding spreading of the Coronavirus. Since one of the course's missions is to motivate students to design for the real world by taking projects from government or private sectors, design studio projects are based on current situations and in collaboration with the real clients. The class of 2020 of second-year studio took the initiative to design public buildings to reduce the risk of COVID-19. Examples of projects for Sustainable Architecture Design Studio presented in this paper include post-COVID-19 eco canteen and 50-bed hospital. The first project was designed for Dairy Farming Promotion Organization of Thailand (DPO or known as Thai-Denmark Farm) and it was sponsored by SIG Combibloc Ltd. as its CSR project. The second project was aimed to design hospitals for the new normal with new COVID-19 section and cohort ward. It was a lesson learned from a voluntary program in which hospital design experts were participated to re- 
design and modify existing public hospitals. The program was hosted by Architect Council of Thailand (ACT) in the early stage of COVID-19 pandemic in Thailand. The BBIT design course runs during the 1st semester (July-November) in 2020. The paper covers teaching and learning methods, assigned tasks or study aspects, design communication techniques as well as results of the first project and the progress of the ongoing one.

\section{Literature Review}

\section{Sustainable Architecture Design Studio}

Due to the increasing impacts of climate change on ecosystems (Warren et al., 2010), sustainability has beome the major concern in every sector including building industry. Architectural education prepares students for their profession. Learners are well equipped with knowledge, creative thinking abilities and skills to transform their ideas into reality. During the educational process, it should enable meaningful learning for sustainable design. Therefore, embedding sustainability within architectural design programs should be of primary concerns for design educators (Grover et al., 2020). Design studio is the core of architectural education (Kurt, 2009). Design studio courses, on one hand, are platforms for students to apply comprehensive knowledge in sustainable architecture design as it requires holistic approach for problem-solving. On the other hand, it is where design educators can implement teaching and learning strategies to enhance performance of architecture students (Soliman, 2017).

Teaching and learning actions could take place in traditional design studios and constructivist design studios. The former is based on a model of apprenticeship and focuses on learning by doing (Kurt, 2009). However, it is found in many cases that students are told what to do so they 'learn about' rather than 'learn to become' in traditional studios. The latter is based on a constructivist view of human perception and thought-processes. Schön (1987) describes design process as a prime example of "reflection in action." Design problems are identified by designers who take action by using a spatial-action language (sketching and drawing). Designers are aware of the problems, relations and changing situations throughout the design proess. This action lets designers improvise more to address unexpected new conditions. As design is the decision-making process, with this approach the designers can evaluate the consequences of initial set criteria, previous decisions, and new opportunities or constraints arising from the decision during the process.

\section{Operating Design Studio}

In order to create constructivist studio environment and encourage critical thinking through teaching and learning, the studios can be operated by acknowledging 3 basic principles: 1) Student centered education, 2) The possibilities of multiple solutions for the problem, and 3) Programs that can change in accordance with studio dynamics (Dizdar, 2015). Activities in design studios include problem identification, research, generating ideas and sketch work, critiques and modeling. 


\section{Design Considerations for COVID-19}

Coronavirus disease 2019 (COVID-19) is an emerging deadly disease caused by the severe acute respiratory syndrome coronavirus 2 (SARS-CoV-2), which was first detected in early December 2019 in Wuhan, China. While the rapid spreading rate is found in the western and temperate climate countries such as Italy, France, Germany, Spain, USA, and the UK, where the range of temperature are between 3 ${ }^{\circ} \mathrm{C}$ and $17{ }^{\circ} \mathrm{C}$, most similar to Wuhan China, Asian tropical countries such as Indonesia, Malaysia, Vietnam, Singapore, and Thailand show slower growth rate. This is relevant to the humid weather as some evidences show that high temperature and high humidity significantly reduce the transmission of COVID19, respectively (Haque and Rahman, 2020).

Since the outbreak, the way we design architecture needs to be re-visited. The pandamic had an impact on public buildings and spaces (Megahed and Ghoneim, 2020). Physical distancing and ventilation effectiveness play an important role in preventing COVID-19 transmission. WHO has prescribed maintaining an interpersonal distance of 1.5 or $2 \mathrm{~m}$ (about 6 feet) to minimize the risk of infection. Nonetheless, more recently published studies suggested distance over $2 \mathrm{~m}$ from an infected person (Bourouiba, 2020; Setti et al., 2020). Some detail studies indicated that $1.6-3.0 \mathrm{~m}(5.2-9.8 \mathrm{ft})$ is the safe social distance when considering aerosol transmission of exhaled large droplets from talking, while the distance can be up to $8.2 \mathrm{~m}(26 \mathrm{ft})$ if considering all droplets under calm air environment (Suna and Zhai, 2020).

For healthcare facilities like hospitals where treatments for patients with or without COVID-19 infection cannot be avoided, it is crucial to control indoor air circulation to protect medical staff and other non-COVID-19 patients from the virus transmission. Having learned from the previous pandemics such as Middle East respiratory syndrome coronavirus (MERS-CoV), severe acute respiratory syndrome coronavirus (SARS-CoV) and $\mathrm{H} 1 \mathrm{~N} 1$ influenza virus, wards must be carefully designed to prevent airflow from the infected patients to healthcare workers on duty (Yu et al., 2017). The computational fluid dynamics (CFD) simulation has been used extensively as it is an effective means to analyse airflow field and virus dispersion inside the wards.

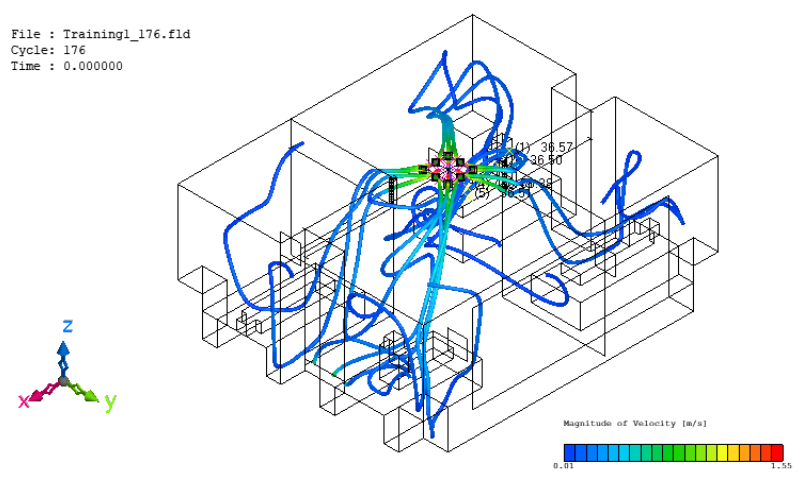

Figure 1. CFD simulation of a 4-bed ward Source: Author, 2020 


\section{Methodology}

There were two projects selected for the study: 1) 100-seat post-COVID-19 eco canteen for DPO in Saraburi province and 2) 50-bed hospital in Bangkok. There were 27 students in the $2^{\text {nd }}$-year studio in total but they were divided into 3 groups supervised by 3 professors. Each project required individual and group consultations as well as team critiques at mid-jury and final jury. Teaching and learning processes followed constructivist studio approach by identifying design problems, assigning tasks for individuals and groups while students were free to use any presentation techniques to communicate their design.

Due to the university policy regarding COVID-19 measures, the students experienced both on-site and online classrooms. Students received online comments to improve their design from the professor who was assigned to their group. Group research was conducted especially for site and program analysis. In lieu of case study visits due to social distancing policy, special lectures were organized to provide specific knowledge for the peojects and comments from clients and experts were welcome.

Assessment methods include observation and analysis of student work in terms of ability to research and design. It is essential for the students to be creative under site and program constraints. As Thai Qualifications Framework (TQF) for Higher Education required learning outcomes from the following categories: 1) Moral and ethics, 2) Knowledge, 3) Cognitive skills, 4) Interpersonal Skills and Responsibility, and 5) Numerical Analysis, Communication and Information Technology Skills, the learning outcomes of design studio projects were adapted to mainly focus on knowledge and skills by considering concept-to-design implementation with integrative knowledge in environmentally responsive design, structure and technology, building regulations, as well as communicative skills.

Special design issues were focused differently for each project. The post-COVID19 eco canteen project emphasized on passive design, daylighting and natural ventilation, in particular. Physical distancing was the key driver to innovative dining space as the canteen must be for the new normal lifestyle of DPO workers. The hospital project focused on flow function and airflow of the new hospital with COVID-19 section as students were required to show separated circulations and negative-pressure cohort ward of which design performance would be analysed by CFD simulation technique at the final jury at the end of the semester.

\section{Results and Discussion}

From architectural teaching and learning perspective, the assessment of both projects was divided into 3 categories to be more specific to each design problem:

1) Knowledge of sustainable architecture design and related fields;

2) Cognitive skills or abilites to understand problems and take actions to solve them;

3) Numerical Analysis, Communication and Information Technology Skills to present design and analytical thinking process. 
Examples of students' work of post-COVID-19 eco canteen are shown below.

\section{BUBLE DIAGRAM}

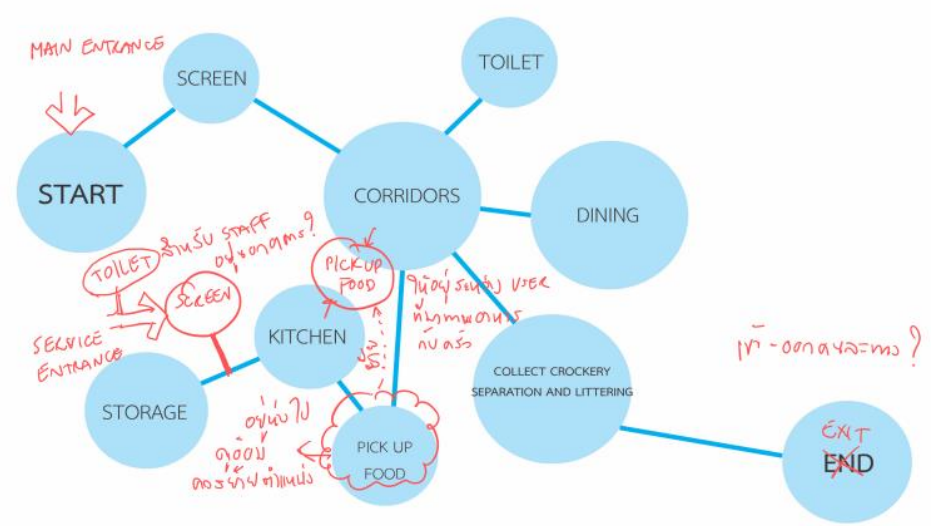

Figure 2. An example of post-COVID-19 eco canteen with online comments Source: Author, 2020

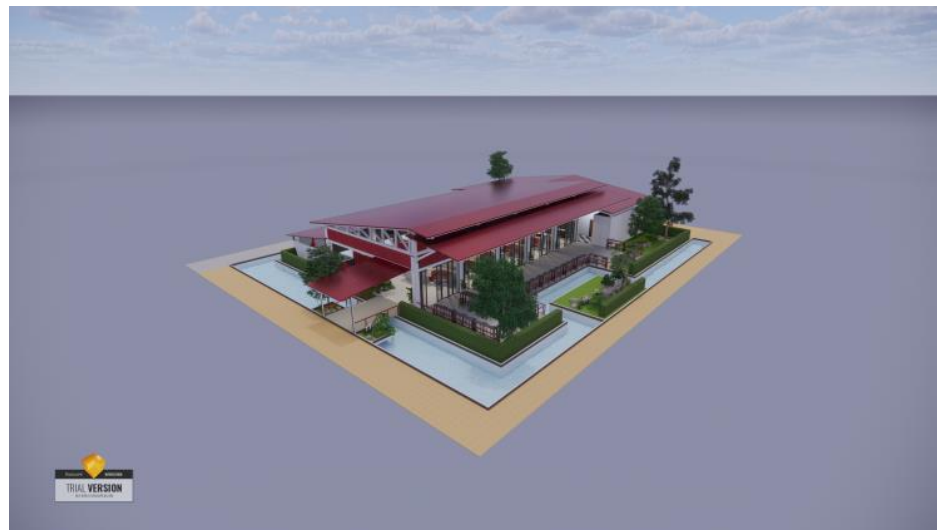

Figure 3. An example of post-COVID-19 eco canteen Source: Author, 2020

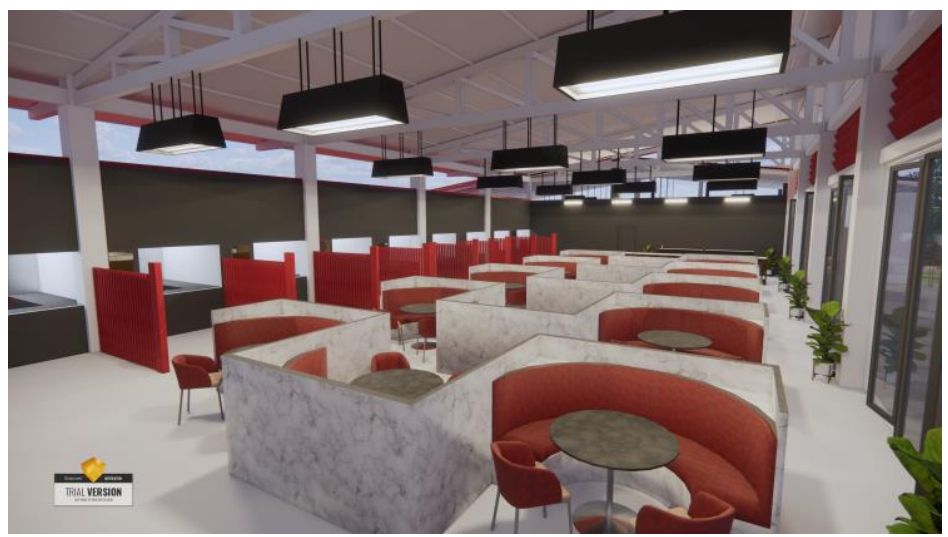

Figure 4. Interior space of an eco canteen designed for physical distancing Source: Author, 2020 


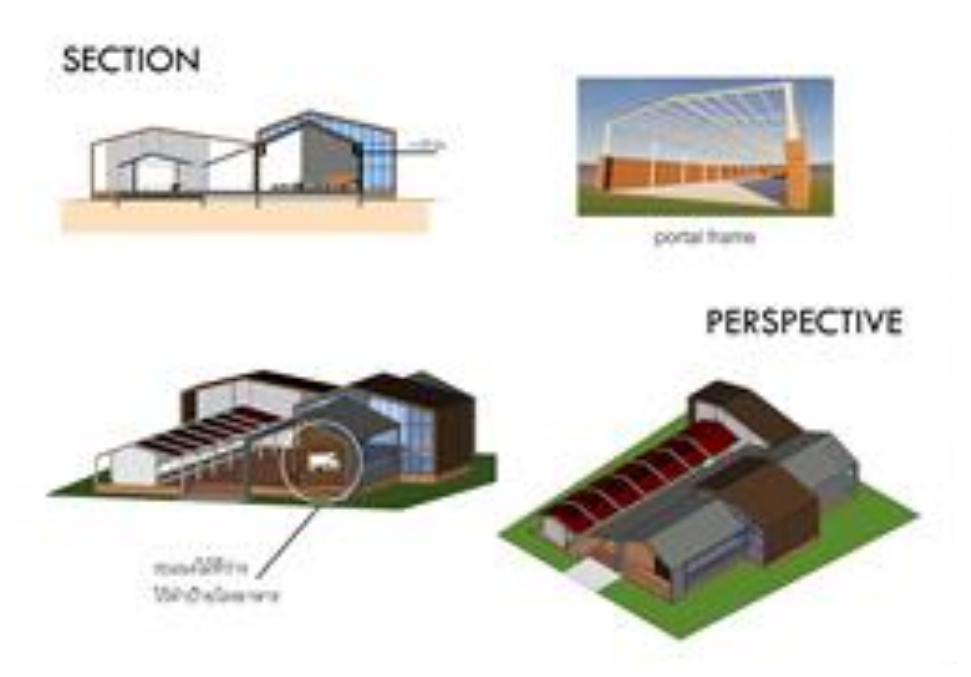

Figure 5. An example of structural design for post-COVID-19 eco canteen Source: Author, 2020

Figures 6-8 present examples of students' work of 50-bed hospital.

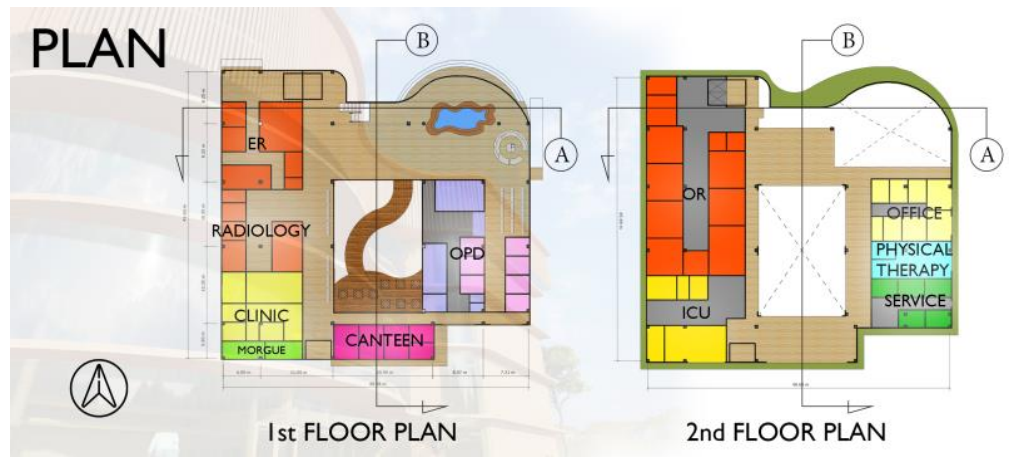

Figure 6. An example of 50-bed hospital Source: Author, 2020
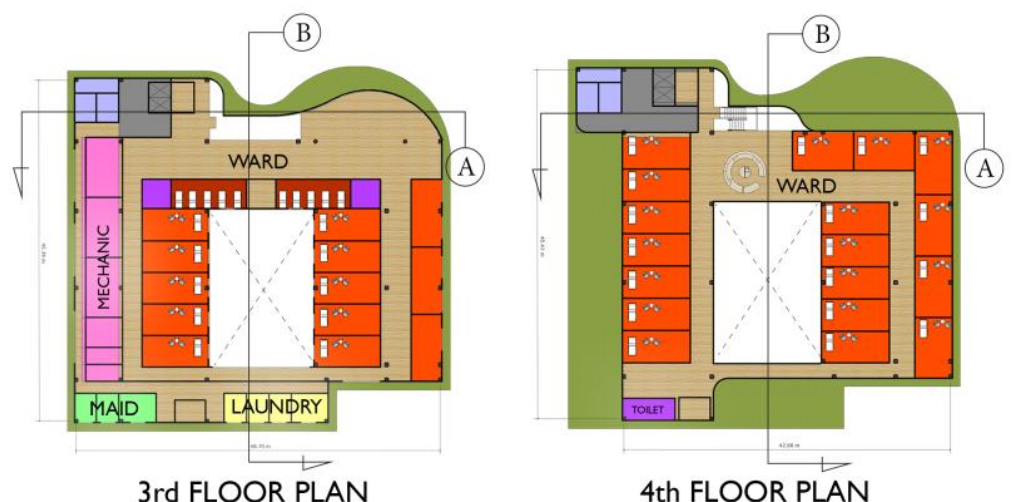

Figure 7. An example of 50-bed hospital Source: Author, 2020 


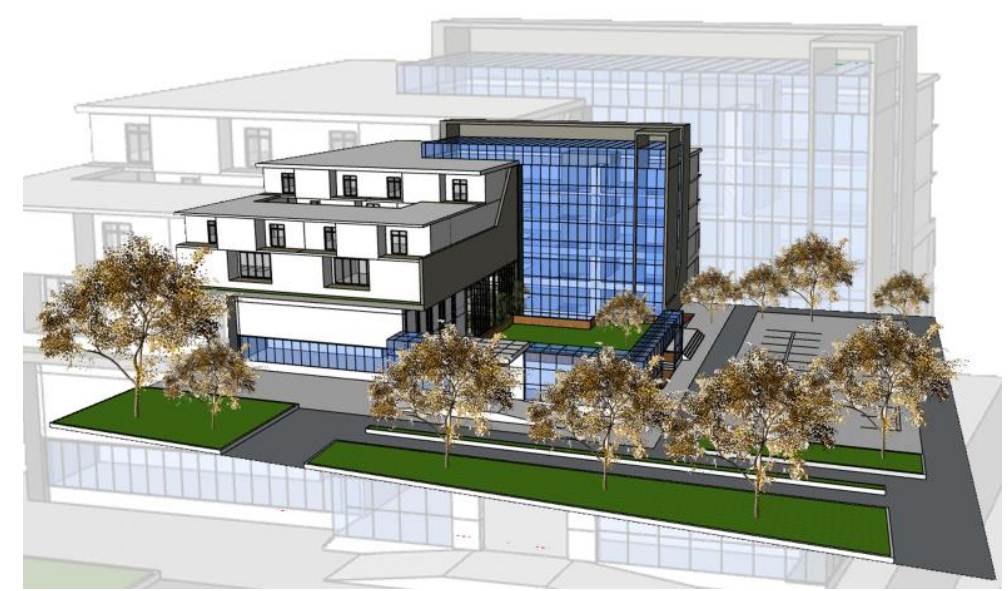

Figure 8. An example of 50-bed hospital

Source: Author, 2020

Leaning outcomes of both projects were compared as shown in graphical format.

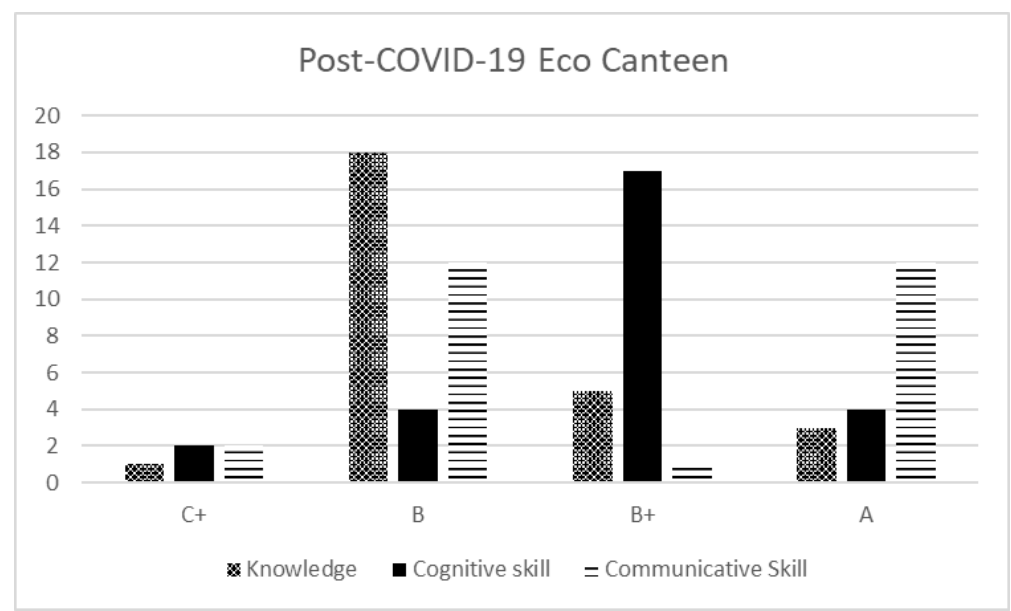

Figure 9. Post-COVID-19 eco canteen learning outcomes

Source: Author, 2020

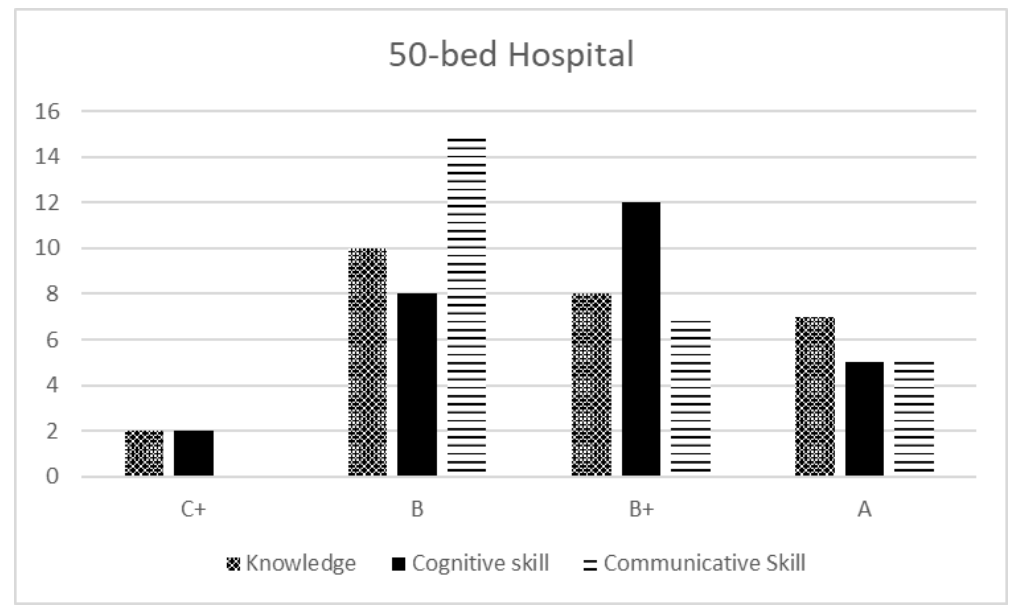

Figure 10. 50-bed hospital learning outcomes

Source: Author, 2020 
The graphs show number of students whose abilities were evaluated in terms of knowledge, cognitive skills and communicative skills. Results were also analysed in percentage format as shown in Table 1 and Table 2.

Table 1. Percentage of students with different learning outcomes from post-COVID-19 eco canteen project

\begin{tabular}{cccc} 
& Knowledge & Cognitive skills & Communicative Skills \\
\hline C + & $3.70 \%$ & $7.41 \%$ & $7.41 \%$ \\
\hline B & $66.67 \%$ & $14.81 \%$ & $44.44 \%$ \\
\hline B & $18.52 \%$ & $62.96 \%$ & $3.70 \%$ \\
\hline A & $11.11 \%$ & $14.81 \%$ & $44.44 \%$ \\
\hline
\end{tabular}

Source: The result of the analysis, 2020

Table 2. Percentage of students with different learning outcomes from 50-bed hospital project

Knowledge Cognitive skills Communicative Skills

\begin{tabular}{cccc}
\hline $\mathrm{C}+$ & $7.41 \%$ & $7.41 \%$ & $0.00 \%$ \\
\hline $\mathrm{B}$ & $37.04 \%$ & $29.63 \%$ & $55.56 \%$ \\
\hline $\mathrm{B}+$ & $29.63 \%$ & $44.44 \%$ & $25.93 \%$ \\
\hline $\mathrm{A}$ & $25.93 \%$ & $18.52 \%$ & $18.52 \%$
\end{tabular}

Source: The result of the analysis, 2020

Based on standard grading system where $\mathrm{A}=80 \%, \mathrm{~B}+=75 \%, \mathrm{~B}=70 \%, \mathrm{C}+=$ $65 \%, \mathrm{C}=60 \%$, none of the students failed or received less than $\mathrm{C}+$. For the postCOVID-19 eco canteen project, results show that in knowledge category, $66.67 \%$ of the students received $\mathrm{B}$ while in cognitive skills category, $62.96 \%$ received $\mathrm{B}+$. In communicative skills category, $44.44 \%$ of student performance received B and A, showing that majority of the students did well in this category.

For the ongoing 50-bed hospital project, results show that, in knowledge category, only $7.41 \%$ of the students received $\mathrm{C}+$ while the rest fall in each grade range rather equally as $37.04 \%$ received $\mathrm{B}, 29.63 \%$ received $\mathrm{B}+$, and $25.93 \%$ received A. Cognitive skills category also shows similar results with a slightly higher percent of students who got $\mathrm{B}+(44.44 \%)$. In communicative skills category, none of the students received $\mathrm{C}+$ which indicated the improvement in design communication. However, more than half of the class $(55.56 \%)$ received $\mathrm{B}$ leaving smaller number in range of $\mathrm{B}+$ and $\mathrm{A}$. This could be due to the more complexity of the second project compared with the first one. Time was limited for preparing physical scaled-models and VDO presentation. Nonetheless, percentage of students with grade A increased in knowledge and cognitive skills categories indicating the ability improvement regardless of the complexity of design problems. By observation during consultation time, the students were more 
enthusiastic with more challenging project as they asked more questions and actively searched for answers and case studies.

\section{Conclusion}

COVID-19 may have driven a lot of changes in all disciplines including architectural design. Sustainability remains the major concern and it must be embedded in architectural design and education. Since design studio is the key teaching and learning platform, design programs should tackle the timely issues or new challenges. From the current study, it shows that design programs for the early year architecture students can be adapted in response to difficult design problem like COVID-19 pandemic. With the constructivist studio approach, students were encouraged to identifiy problems, finish individual and group's tasks, and prepared for changing situations. The new normal recognized in design process has become the new challenge that stimulates students' curiosity.

\section{Acknowledgements}

The author would like to present sincere gratitude to SIG Combibloc Ltd. and Dairy Farming Promotion Organization of Thailand (DPO) for providing all the information and support. Without the voluntary program hosted by Architect Council of Thailand (ACT), there would never be design studio programs that take into account problems of the real-world.

\section{References}

Bourouiba, L. (2020). Turbulent gas clouds and respiratory pathogen emissions: Potential implications for reducing transmission of COVID-19. The Journal of the American Medical Association, Vol. 323(18), 1837-1838.

Dizdar, S. I. (2015). Architectural education, project design course and education process using examples. Procedia - Social and Behavioral Sciences, 176, 276-283.

Grover, R., Emmitt, S., \& Copping, A. (2020). Critical learning for sustainable architecture: Opportunities for design studio pedagogy. Sustainable Cities and Society, 53, 101876.

Haque, S. E., \& Rahman, M. (2020). Association between temperature, humidity, and COVID-19 outbreaks in Bangladesh. Environmental Science and Policy, 114, 253-255.

Kurt, S. (2009). An analytic study on the traditional studio environments and the use of the constructivist studio in the architectural design education Procedia Social and Behavioral Sciences, 1, 401-408.

Megahed, N. A., \& Ghoneim, E. M. (2020). Antivirus-built environment: Lessons learned from Covid-19 pandemic. Sustainable Cities and Society, 61, 102350. 
Schön, D. A. (1987). Educating the reflective practitioner. San Francisco: JosseyBass.

Setti, L., Passarini, F., De Gennaro, G., Barbieri, P., Perrone, M., Borelli, M., \& Miani, A. (2020). Airborne transmission route of COVID-19: Why 2 meters/6 feet of interpersonal distance could not be enough. International Journal of Environmental Research and Public Health, 17(8), 2932. Retrieved from https://doi.org/10.3390/ijerph17082932

Soliman, A. M. (2017). Appropriate teaching and learning strategies for the architectura ldesign process in pedagogic design studios. Frontiers of Architectural Research, 6, 204-217.

Suna, C., Zhiqiang Zhai (John). (2020). The efficacy of social distance and ventilation effectiveness in preventing COVID-19 transmission. Sustainable Cities and Society, 62, 102390.

Yu, H. C., Mui, K. W., Wong, L. T., \& Chu, H. S. (2017). Ventilation of general hospital wards for mitigating infection risks of three kinds of viruses including Middle East respiratory syndrome coronavirus. Indoor and Built Environment, 26(4), 514-527.

Warren, R., Price, J., Fischlin, A., Santos, S. d. 1. N., \& Midgley, G. (2010). Increasing impacts of climate change upon ecosystems with increasing global mean temperature rise. Climate Change. DOI: 10.1007/s10584-0109923-5 